\title{
Literacy and Children's literature: Evidence from Actual Classroom Practice
}

\author{
Salwa Al Darwish \\ Correspondence: Salwa Al Darwish, Associate Professor of Public Authority for Applied Education \& Training, College \\ of Basic Education, Al Safat PO Box 276, 13003, Kuwait.
}

\author{
Received: November 24, 2014 Accepted: December 10, 2014 Online Published: December 18, 2014 \\ doi:10.11114/jets.v3i1.591 \\ URL: http://dx.doi.org/10.11114/jets.v3i1.591
}

\begin{abstract}
This qualitative study aims at detecting areas that requires to be developed in the EFL reading program in elementary stages in Kuwaiti public schools by using children's literature. It also examines the reading program in the public elementary curriculum. The participants were six English language major students from the College of Basic Education in Kuwait. Those six students were in their senior year and have just recently finished with the micro- teaching course followed by their practicum and then as independent EFL teachers. The findings revealed that young learners should be encouraged to use books at an early stages which will later bring pleasure to these students. Furthermore, environment plays an important role in reading pleasure.
\end{abstract}

Keywords: literacy, practice, children's stories, elementary, micro- teaching, practicum, EFL, modeling

\section{Introduction}

The researcher, as a teacher trainer for teacher trainees of young learners (elementary students) for over a decade, has had the good fortune to observe young learners in the process of learning to read and write. In addition, through numerous workshops which the researcher have conducted for elementary school teachers over the years, she had the opportunity to observe a great many teachers from public schools in Kuwait who didn't integrate two of the four skills (reading and writing) in their lesson plan. In fact, the researcher discovered that many of the young learners who were successful in the reading process had been given a head start by adults who had introduced them to the pleasure and delight associated with books and reading. Yet, this discovery was revealed when the researcher was observing young learners in international private schools in Kuwait where mainly the student population is non-Kuwaiti. Moreover, Qafleshi has acknowledged that home is considered the first environment followed by the community where young learners have the access to literacy (2011). Yet, for years literature has been documented as an appreciated resource for reading and writing instruction. A Children's books are different from adults' books: they are written for a different audience, with different skills, different needs, and different ways of reading; equally, children experience tex ts in ways which are often unknowable, but which many of us strongly suspect to be very rich and complex (Hunt, 2007, P.3). Nevertheless, in English as a Foreign Language (EFL) context, full-length novels or fiction may not provide input as comprehensible as stories written for children nor model examples of language style and length for production. Thus, for several years the researcher has attempted to use children's literature in her composition course and developed a task of reading and writing stories to empower her student writers and activate their imagination.

\subsection{Rational}

First and foremost, literature provides delight and enjoyment. Much of what is taught in school is not particularly enjoyable especially in Kuwaiti Public Elementary Schools, teachers have traditionally allowed kids little choice of their reading, instead marching them through an endless lockstep series of Ministry of Education -selected and teacher-controlled readings. Mostly, this reading has been done with a focus on memorizing details, not on getting the big picture. Ironically, as a result of this, young learners don't get enough practice with reading to get good at it-or to like it. Parents and academic authorities may squeeze their hands about having a nation of nonreaders, but the public schools in Kuwait with the traditional school reading programs are practically designed to ensure that the young learners never voluntarily pick up a book once they graduate. This paper aims at identifying areas that need to be improved in the EFL reading program in elementary stages. Accordingly, the following research questions will be answered: 


\subsection{Research Questions}

1. Do we consider literature for EFL learners suitable to engage young learners in reading?

2. How could the EFL teachers for young learners implement the reading program?

\section{Literature Review}

The use of literature has been acknowledged as a vehicle for encouraging academics intellectual, cultural and linguistic learning (Osters 1989). Popp believes that teachers who read aloud model the pleasure of reading, as they expose their students to new information, rich vocabulary, and good grammar. At the same time, the young learner's imagination is stimulated, attention span stretched, listening comprehension improved, emotional development is nurtured, the reading-writing connection established, and where they exist, negative attitudes reshaped to positive (2006). Popp adds that elementary school educators, who integrate language learning and literature successfully throughout the curriculum, share a common belief that children learn best through active participation (2006). Also, Barone and Xu reminds the educators around the world that the process of young learner's becoming literate in a language begins with the interactions with the environment and the guidance of their parents (2008).

Dolores Durkin (1961) studied children who learned to read before entering first grade. She found that all the early readers had been read to regularly at home and that their families had a high regard for books and reading (p. 164). Likewise, Sage and other L2 researchers and practitioners who strive for communication as the primary goal of instruction encourage the use of literature especially when literature readers within the four walls of the classroom will pick up the target language in a whole context rather than memorizing words and rules (1987). Another example is Dorothy Cohen (1968) who studied 580 academically retarded second grade young learners and found that those who were given the opportunity to listen to carefully selected books and read to them aloud every day of the school year made significantly higher gains on tests. Moreover, Palardy (1997) maintains that literature helps the readers better understand themselves, the world they are living in, and the aesthetic values of the written text. Furthermore, Palardy adds that literature serves as a treasured source of language input in the EFL context especially when student readers will develop the opportunity to improve insights and understandings of the cultures and people of the world, and to gain new perspectives by testing their ideas with those found in books (p. 67).

When we come across variety of literature sources to choose from, we need to take three important factors into consideration: language, content, and length to select the appropriate materials for EFL students especially if they are young learners.

Krashen's (1982) Input Hypothesis emphasizes the language as the first mentioned above factor through $(i+1)$ in which $\mathrm{i}$ referring to the learner's current level of competence and $i+1$ representing a slightly higher level which can be comprehended because of nonlinguistic and contextual factors. By doing this, the input should not be so simple as to kill readers' interest, nor so difficult as to hinder their understanding. Furthermore, the clarity of the target language can also be enhanced by some non-linguistic cues such as illustrations or story structure (alien, 1989). The text should be challenging but not frustrating. If we come to the second factor, content, literature supports students to relate their own experiences and feelings to the reading. With regard to the third factor, length, literature books particularly the long ones often make the students' anxiety increases, and they become impatient and unwilling to wait till the end to know what happens to the story. To summarize, in an EFL classroom children's literature can be considered an appropriate material for young learners' literacy development due to its simple language styles, inserted cultural information, and comfortable length.

\section{Methodology}

The research paper took place in four public elementary schools within three school districts in Kuwait. It was carried out over the fall and spring of 2012. The study started at the beginning of the new Kuwaiti school academic year (September, 2012) with one week of observation. This was followed by another two weeks at about the middle of the semester (November-December, 2012), and then on a weekly bases the researcher had to visit the classrooms where the six teachers were teaching. The participants of this research paper started with ten student teachers and ended with six teachers. To begin with, the participants were all English language major students from the College of Basic Education in Kuwait, a college that trains and graduates teachers mainly for primary levels. Those 10 students were in their senior year and have just recently finished with the micro- teaching course that was taught by the researcher. The ten student teachers were selected based on the grade they were assigned to do their practicum. For this research paper, fifth grade was selected from the elementary public schools because these students in this grade level compared to grade (1-4) were exposed in a way to some reading and writing materials from the Kuwaiti Ministry of Education. The reading material that was imposed by the ministry was mainly short paragraphs and sentences in which the young learners repeat whatever the teacher has read. Therefore, those fifth graders in the public schools had limited vocabulary words, and did 
not read or did not realize they had the potential to read any children's literature before. Moreover, just about most of them had not been given much chance to practice real writing before. In addition, the existing teachers excluding the 10 student teachers had centered their attention on English word usage and sentence structures as well as translation to better prepare students for higher grade levels and ultimately the college entrance examinations.

Through the micro- teaching course, the researcher explained the way on how to read stories in classes by showing the essential elements. The researcher modified the way for the student teachers on the procedure of how to read and attract young learners' attention to the books. The researcher had to guide the student teachers on the way of how to make reading children's literature easy and memorable. The researcher showed the student teachers the procedure by firstly reading the story slowly changing the voice tune and the pitch whenever vocabulary words need more clarification, and pausing sometimes for vivid characters and effects and checking for comprehension. Also, the researcher emphasized the importance of questioning before, during and after reading and how productive these questions would be once the children learn to ask their own questions to initiate the search for meaning. Before reading, the student teachers had to draw young learners' attention by imposing one question, What do you think the story is about based on the title?; and after the reading, other questions were directed to the young learners such as: Do you like the ending of the story?; Who is the main character?; Are the images of the characters in the story clear to you?; Are they clearer when they speak?; Can you tell the story from your perspective?; What was the best part of the story you liked? Finally, book discussions was emphasized to take place every day during the last fifteen minutes of one class period for sustained silent reading.

After the micro- teaching course, the researcher was observing the participants in the schools as they were implementing the reading segment of the class period during their practicum. Then, the researcher carried out an informal follow- up survey to discover how and to what extent the EFL teachers, excluding the research participants, are actually using children's story in their classrooms before the participants start their carrier as EFL teachers. Furthermore, once these participants (student teachers) graduated, the researcher was in contact with six of the ten because these six EFL teachers had the opportunity to be assigned to teach fifth graders. As a nonparticipant observer, the researcher observed each teacher in the classroom for 40 minutes a day, once a week. Thus twenty-eight observations were made for a whole academic year for each teacher. During and after this period, the researcher collected the student teachers' diaries and their lesson plans.

Furthermore, and because parents are children's first teachers, the researcher went and visited some private schools and interviewed some parents just to identify the contributions and involvement that parents make in their children's language and literacy development. The reason for the researcher to interview these parents in these private schools because literature is being integrated starting in the kindergarten curriculum.

\section{Data Analysis \& Discussion}

This paper is designed as a qualitative study with a multi-method focus, involving an interpretive, naturalistic approach. Triangulation was carried out through non participant observation, parents' interviews, and the teachers' (used to be student teachers) diaries and their lesson plans.

\subsection{Observation}

\subsubsection{Story Books}

Through the observation, the researcher noticed the six participants had to use stories which are about three to four pages long at the beginning and then exceeded the number of pages as they advanced. Moreover, the stories mostly contained universal themes, which students can always have something to relate to, and the language used in these stories is simple, directs and natural. These story books that the teachers have mainly used consisted of animals and humor, for instance, which are generally popular across age levels.

\subsubsection{Teachers}

The reading process needs skillful readers who can use unconscious rational approaches to get ready before reading, construct meaning during reading, and take ideas after reading successively (Daniels, 1994). Based on this, before the reading session, the six teachers developed motivation, activated prior knowledge and developed questions. During the reading session, two teachers wrote all the text on index cards, one word or sentence per card. Children were reordering the cards as they were comparing them to their storybooks. This builds sight-word recognition, awareness of sentence structure, and visual memory.

The teachers' experiences with literature give children new perspectives on the world. Accordingly, the six teachers visualized the text meaning to the young learners, and made some connection to their real life environment. Finally, after reading, the teachers reread the story to enhance the meaning and then the young learners had to retell, answer the teachers' earlier questions and discuss some unfamiliar parts of the story. 
Meanwhile, teachers commented on their students' growing capacity to generate significant questions in the analysis of stories and to compare themes, characters, and narrative patterns.

Consequently, these teachers also witnessed their students' growth in attention span, comprehension skills, and critical thinking. Moreover, some teachers after explaining the topic of the day for the whole classroom and once some learners finished earlier than others, they had the chance to do a silent reading period to allow for independent reading and the quest of personal interests. As a result, the regularity of these free-reading periods suggests to the young learners that reading is valued as a private, personal experience.

In fact, if most teachers remember being read to as children-by parents, siblings, or grandparents, later as a teacher, your memory of this experience is exciting and comforting, you will pass along this gift to your students, convinced of the pleasure that reading aloud brings to listeners. As well, a special bond forms between teacher and students during these read- aloud times.

In fact, whether reading aloud or silently, the six teachers collected sets of good books, and assisted young learners to select the right books based on their level of reading abilities; at the same time, observed and listened to young learners reading, and discussed with the kids who struggled especially the students who were forced to stop several times per sentence to look up a word meaning and pronunciation.

The six teachers were sitting with the young learners and reading together, pointing to each word as she says it; As well, pointing to the pictures that correspond to the text, too. After repeated readings, the young learners were able to read the books independently.

Students who were behind were simply coloring the books, and working at their own pace. However, some teachers were really emphasizing on phonics in the storybooks within context. They used the text in the books to teach sound-symbol correspondence and build awareness of the sounds of English: "stars starts with S" pointing to the S. Likewise, some teachers also selected another key role: that of fellow reader. They joined a group not as the teacher, but as an equal classmate. Obviously, teachers followed this step only when the kids haven't previously read the book.

\subsubsection{Young Learners}

The first week of the school year young learners couldn't comprehend simple words and phrases; they lacked basic English vocabulary and the knowledge of grammar. They were also withdrawn and shy. Though silent, they were absorbing language all around them and processing it in their own time. After few weeks, the young learners used basic vocabulary in forming sentences, began to follow basic grammar patterns, and showed greater independency. They were struggling to elaborate upon ideas, but they spoke in longer phrases and understood most of what was said.

The young learners were encouraged to reflect on what they have heard or read and to express their thoughts orally. As Carol Chomsky's study (1972) of the language development of children from six to ten explains, the child who reads (or listens to) a variety of materials benefits from a range of linguistic inputs that is unavailable to the non-literary child's (p. 23).

Also, through observation the young learners became familiar with the complex vocabulary and syntax of written language as well as the variety of style and content in written materials. Carol Chomsky's studies of linguistic development highlight the crucial role of language competence in the reading process. If comprehension is the goal of reading instruction, the reading program must include learning experiences designed to build children's store of cognitive structures and language competence.

Over the course of the school year the researcher observed evidence of increased interest and involvement in reading and a definite improvement in the students' ability to discuss books in depth. Eventually, students had the chance to relate stories to their own experiences, interests, and backgrounds. The young learners felt connected to the lives of others as they entered an imagined situation with their emotions tuned to those of the story.

\subsubsection{Questioning}

The teacher's questions are designed to assist the comprehension of meaning, and to focus attention on narrative elements and literary patterns. Specific questions were used to generate reflection and discussion during reading process. In addition, questions were designed to help the young learners understand and enjoy each story as well as to evolve a conceptual framework for understanding stories in general. Usually, questions build bridges between the story world and the child's own world of reality, imagination, and dreams. Some of these questions when the teachers asked encouraged the young learners to relate stories to their own experience, and to gain insights about their own lives and their relationships to others. Sometimes, the students' questions were related to the vocabulary, characters, illustrations, or other aspects of the storybook. They were often, questions that were not answered directly by the book. This demonstrated curiosity on behalf of the students. 


\subsection{Interviewing}

\subsubsection{Parents}

By interviewing some of the parents specially the young learners who showed their interest and ability to read in class; the following were some of the parents' comments: One Mom said: "Both my husband and I started reading to them immediately after they were born." Another one added "I read to make an emotional connection to let them hear my voice, to let them hear and learn the language, to fill time in the day, to set a routine, for fun (some were nursery rhymes). Another mom added "Yes we both read to them every night at bedtime. Now that they are older and have school books they do the majority of the reading during the day. We also have audio storybooks we listen to in the car.

Moreover, one mom started with board books like Goodnight Moon and the Sandra Boynton Books with a lot of pictures. One mom added, it's preferable to allow the child to advance than to be held back with reading material that is too immature for her/ him; consequently, she/ he will be hearing a broader vocabulary. She continued by saying "Don't forget when a child is being read to, a lot goes on in her/ his mind". In general, some moms started reading to their kids with board books, nursery rhymes and picture books when they are in bed, on their lap, sitting on the floor, coarsest, everywhere during the day the most, but always at night.

\subsection{Diary \& Lesson Plan}

The teachers described in their diaries that they had initially shared several children's stories with their top reading individuals. These individuals responded to each story with great excitement, and most of them were stimulated to explore other books on their own. They added that the slower the students are in academic progress, the more difficult it is for them to deal with words out of context.

The teachers stressed that school norms and values supported a hidden goal of teaching toward future examinations. They felt caught in a dilemma between the official requirement to emphasize listening and speaking and the knowledge that these young learners would be expected to begin taking examinations in reading and writing English when they reached third grade. Teachers were concerned that the young learners would be taken by surprise in third grade, not prepared to remember what they had covered in class, and not far enough advanced in reading and writing. Since the teachers would be held responsible if these students did not do well in third grade, they had an interest in trying to introduce a little more formal work in the early grades than the official curriculum encouraged. Also, teachers and departments felt a responsibility to the more motivated students to prepare them, throughout elementary and secondary school, to pass entrance examinations to the higher-ranking universities (which test reading, writing, and translating English, and knowledge of grammar, but not speaking and listening).

\section{Conclusion}

First, literature clearly plays an important role in all aspects of oral language development. Similarly, it develops young learner's imagination and helps them consider people, experiences, or ideas in new ways. It takes time for reading and literature to grow in a classroom. Children's literature, when selected carefully can be a valuable resource for integrative EFL learning in terms of classroom practice. Also, listening to stories introduces young learners to patterns of language and extends vocabulary and meaning. Words that speak to the senses will enrich the vocabulary of students and provide them with a high-quality listening experience.

Stories tend to raise young leaner's imagination and the desire for craving creativity.

Secondly, the most important aspect of the classroom environment is the teacher. She or he creates the climate of the classroom and arranges the learning environment. When teachers consistently nurture young learner's enjoyments of literature by reading a loud exciting, well- selected books, and by giving the young learners time to read and discuss books in literature groups, the young learner's appreciation for quality literature will grow.

Furthermore, knowing literature, the teacher may tune in to where the young learners are and extend their thinking and understanding. The teacher does not have to rely on the questions in a teacher's manual; she is free to ask questions directly related to the need of the children in the class. As well, when the teachers are an active participant rather than the director of the group, young learners more readily collaborate to fill their own gaps in understanding and make meaning together.

Thirdly, as the young learners gain increased awareness of the lives of others, as they vicariously try out other roles, they may develop a better understanding of themselves and those around them. It is obvious from their discussion that they were gaining a greater sense of form and were beginning to see more in books than just story. The goal of all reading programs should be not only to teach young learners to learn to read, but to help them learn to love reading, to discover joy in reading. Another important purpose for using real books in a reading program is to help young learners connect literature with their own lives. 
Finally, it seems that the success of a reading program should be measured in terms of the number of students who eventually establish the pattern of reading for individual satisfaction. One of the primary purposes of giving book talks, telling stories, and reading aloud to young learners is to motivate them to read. A major goal of every school should be to develop students who not only can read but who do read, who love reading and will become lifetime readers. Through this research paper, the researcher has designed an instructional model through which young learners would be given every opportunity to learn about the world of books and to derive pleasure and meaning from their reading experiences.

\section{References}

Allen, V. G. (1989). Literature as a support to language acquisition. In P. Rigg \& V. G. Allen (Eds.), when they don't all speak English: Integrating the ESL student into the regular classroom (pp.55-64). Urbana IL: National Council of Teachers of English.

Barone, D., \& Xu, S. (2008). Literacy Instruction for English language Learners Pre-K-2. The Guilford Press, New York.

Chomsky, C. (1972). Stages in Language Development and Reading Exposure. Harvard Educational Review, $42,1-33$.

Daniels, H. (1994). Literature Circles: Voice and Choice in the Student-Centered Classroom. Pembroke Publishers Limited, Canada.

Hunt, P. (2007). Understanding Children's literature. Routledge Press. ( $2^{\text {nd }}$. Edition)

Krashen, S. (1982). Principles and practice in second language acquisition. Oxford: Pergamon Press.

Oster, J. (1989). Seeing with different eyes: Another view of literature in the ESL class. TESOL quarterly, 23(1), 85-103. http://dx.doi.org/10.2307/3587509

Palardy, J. M. (1997). Another look at literature-based instruction. Education, 118(1), 67-70.

Popp, M. S. (2006). Teaching Language and Literature in Elementary Classrooms: a resource book for professional development. $2^{\text {nd }}$.Ed. Lawrence Erlbaum Associates, Inc., Publishers.

Qafleshi, E. (2011). Bellaterra Journal of Teaching \& learning language \& Literature, 4(4), 48-58. http://dx.doi.org/10.2307/3587509

Sage, H. (1987). Incorporating literature in ESL instruction. Englewood Cliffs, NJ: Prentice- Hall.

\section{(cc) $\mathrm{Br}$}

This work is licensed under a Creative Commons Attribution 3.0 License. 